\title{
Kunnskapsbasert praksis i norske fagbibliotek
}

\section{Af Lena Victoria Nordheim}

\begin{abstract}
Artiklen prcesenterer arbejdet med kunnskapsbasert praksis $(K B P)$ (et scerligt norsk begreb, der er en overscettelse af evidence-based practice, EBP) $i$ norske forskningsbiblioteker med sarligt fokus på sundhedssektorens biblioteker. Artiklen opererer med en bred definition af KBP, hvor kundskaben hidrører fra tre kilder: professionen, brugerne og forskningen. Det understreges $i$ artiklen, at arbejdet med KBP er todelt: rettet mod forskningsbibliotekernes brugere og mod bibliotekernes egen praksis. Artiklen prasenterer forskellige aktiviteter i forskningsbiblioteker relateret til KBP: kurser i bl.a. statistisk metode, seminarer, en sarlig, akkrediteret KBP videreuddannelse, lasegrupper og besøg af internationale evidenskapaciteter. Artiklen kommer også ind på kvaliteten af den bibliotekariske evidensbase og på mulighederne for at producere systematiske reviews for bibliotekfeltet. Endelig understreges betydningen af netvoerksdannelse og bibliotekarprofessionens centrale rolle både med hensyn til både at konsumere og generere forskning.
\end{abstract}

Lena Victoria Nordheim er ansat som høgskolelektor ved Senter for kunnskapsbasert praksis, Høgskolen $i$ Bergen, Lena.Victoria.Nordheim@hib.no

\section{Innledning}

Kunnskapsbasert praksis er en tenke- og arbeidsmåte som skal bidra til å utvikle praksis gjennom systematisk og reflektert bruk av ulike kunnskapskilder (Booth \& Brice, 2004). I hovedsak dreier det seg om kunnskap fra tre kilder: profesjonsutøverens egen erfaring, kunnskap og preferanser fra praksisfeltets brukere, og kunnskap fra forskning.

I denne artikkelen vil jeg se nærmere på de norske fagbibliotekenes rolle i kunnskapsbasert praksis. Jeg tar til dels utgangspunkt i de helsefaglige miljøene, der denne arbeids- og tenkemåten er mest utbredt. Jeg vil imidlertid også vise til praksis og eksempler som gjelder alle typer fagbibliotek.

\section{Kunnskapsbasert praksis i Norge}

I Norge, i likhet med andre land, er det helsesektoren som har vært i front for å anvende kunnskapsbasert praksis. Trinnene i kunnskapsbasert praksis er imidlertid universelle og kan overføres til alle praksisfelt, herunder bibliotekfeltet. Det handler for det første om å reflektere over praksis og identifisere egne kunnskapshull. Dernest å formulere praksisnære spørsmål, for så å søke etter relevant forskningslitteratur og vurdere påliteligheten av denne. De siste og mest utfordrende trinnene i prosessen består i å anvende kunnskap fra forskning sammen med egen erfaring og brukernes kunnskap og erfaringer, og til slutt evaluere om en eventuell endring av praksis har 
ført til forbedringer og fremskritt (Booth \& Brice, 2004).

Det norske begrepet "kunnskapsbasert praksis" er en oversettelse og tilpasning av det engelske begrepet "evidence-based practice". Begrepet ble lansert av en forsknings- og formidlingsgruppe ved Statens institutt for folkehelse (nå Folkehelseinstituttet) tidlig på 2000-tallet, og ble første gang definert og forklart i en bok om kunnskapshåndtering rettet mot leger og medisinerstudenter (Bjørndal, Flottorp, \& Klovning, 2000). Begrepet "kunnskapsbasert praksis" og dets innhold er gjenstand for en stadig debatt i de norske akademiske miljøene, og det lever side om side med det direkte oversatte begrepet "evidensbasert praksis" (Grimen \& Terum, 2009). Et søk på "kunnskapsbasert praksis" avgrenset til norskspråklige sider i Google viser imidlertid at begrepet er godt etablert, det gir ca. 24000 treff. Til sammenligning gir et søk på "evidensbasert praksis" med samme avgrensning ca. 10500 treff (15.01.2011).

Fagbibliotekarens rolle i kunnskapsbasert praksis er todelt. På den ene siden er bibliotekaren en medarbeider og samarbeidspartner for andre faggrupper som arbeider kunnskapsbasert. På den andre siden kan og bør bibliotekarer overføre tenke- og arbeidsmåten til eget praksisfelt, vi snakker da om kunnskapsbasert bibliotekpraksis (Booth \& Brice, 2004).

\section{Fagbibliotekaren som tilrettelegger for kunns- kapsbasert praksis}

I norske fag- og forskningsbibliotek, og særskilt i de helsefaglige miljøene, er det bibliotekaren som støttespiller for andre profesjoners kunnskapsbaserte praksis som hittil har fătt mest oppmerksomhet. Norsk bibliotekforenings Spesialgruppe for medisinog helsefag $(\mathrm{SMH})$ har siden slutten av 1990-tallet arrangert en rekke seminarer og kurs om kunnskapsbasert praksis i helsefag for både medlemmer og ikke-medlemmer. Kunnskapsbasert praksis har vært et av de mest populære kurstemaene i SMHs snart 60 år lange virke. Hensikten med kursene har vært å skolere fagbibliotekaren i ulike verktøy relevante for de ulike trinnene i KBP, herunder kilder for systematiske oversikter slik som Cochrane Library ${ }^{1}$. Behovet for slike kurs har meldt seg som følge av at ansatte i fagmiljøene selv har deltatt på slike kurs, for så å søke hjelp og videre opplæring i eget bibliotek i etterkant. Flere helse- og undervisningsinstitusjoner har dessuten kunnskapsbasert praksis som satsningsområde i sine strategiske planer, slik som ved Sykehuset Innlandet og Høgskolen i Bergen. Dette har vært retningsgivende for bibliotekets tjenester, ikke minst når det gjelder undervisning og opplæring. En del bibliotekarer underviser sågar helsearbeidere $\mathrm{i}$ kritisk vurdering av forskningslitteratur, slike kurs tilbys blant annet av bibliotekarer ved Oslo Universitetssykehus og Nasjonalt kunnskapssenter for helsetjenesten.

Å utarbeide systematiske oversikter står sentralt i kunnskapsbasert praksis (Grant \& Booth, 2009). En systematisk oversikt er en oversiktsartikkel hvor forfatterne har brukt en systematisk og tydelig fremgangsmåte for å finne, vurdere og oppsummere enkeltstudier på samme tema. Hensikten er å gjøre forskning lettere tilgjengelig for praksisfeltet. Systematiske og omfattende litteratursøk utgjør en viktig del av det metodiske arbeidet, det er derfor vanlig at en fagbibliotekar deltar i forskergruppen som utarbeider oversikten (Grant \& Booth, 2009). I Norge har Nasjonalt kunnskapssenter for helsetjenesten (Kunnskapssenteret) et særskilt ansvar for å systematisk oppsummere og formidle forskning om effekt av helsetjenester til praksisfeltet. Ved senteret er det ansatt forskningsbibliotekarer som utfører litteratursøk for kunnskapsoppsummeringer, flere av dem er også prosjektledere for slike oppsummeringer. Kunnskapssenteret drifter i tillegg Helsebiblioteket ${ }^{2}$, et nasjonalt elektronisk bibliotek for den offentlige norske helsetjenesten. Gjennom Helsebiblioteket har hele Norge tilgang til internasjonale kilder for oppsummert forskning, herunder Cochrane Library.

Internasjonalt har fremveksten av kunnskapsbasert praksis i helsetjenesten ført til at man har børstet støvet av en spesiell type bibliotektjenester, såkalte kliniske bibliotektjenester (Rosall et al., 2008). Slike tjenester er først og fremst prøvd ut i sykehus, der bibliotekarer regelmessig deltar på avdelingenes fagmøter, eller er med på selve pasientrunden. Dette gir bibliotekaren innblikk i klinikernes spørsmål, og de kan derfor gjøre målrettede litteratursøk i relevante databaser og andre kilder. Slik bistår bibliotekaren pasientbehandlingen direkte. Konseptet ble først innfort i USA på 1970-tallet (Rosall et al., 2008). Ved Universitetsbiblioteket i Oslo er det ansatt én bibliotekar som koordinerer kliniske bibliotektjenester, det prøves ut i småskala til ansatte ved Oslo Universitetssykehus, Rikshospitalet. 


\section{Fagbibliotekaren som kunnskapsbasert praktiker}

Ikke unaturlig var det i det helsefaglige bibliotekmiljøet man først så relevansen av å overføre prinsippene for kunnskapsbasert praksis til bibliotekfeltet (Booth \& Brice, 2004), og slik har det til dels også vært i Norge. Forankringen i helsefagene til tross, kunnskapsbasert praksis som modell og arbeidsmåte er også relevant for andre fagbibliotek. Bibliotekutredningen, den nasjonale strategien for hele biblioteksektoren frem mot 2014, har kompetanseutvikling for ansatte som ett av totalt tre målområder (ABMutvikling, 2006). Strategien nevner ikke kunnskapsbasert bibliotekpraksis eksplisitt, men det slås fast at "bibliotekene trenger forskningsbasert kunnskap som kan bidra til å utvikle praksisfeltet" (ABM-utvikling, 2006, s. 37), og videre at "biblioteksektoren skal bygge på relevant forskning om bibliotekenes tjenester og bibliotekene som samfunnsinstitusjoner" (ABM-utvikling, 2006, s. 38). Dette gir føringer for alle typer bibliotek, herunder fagbibliotekene. Sammen med egen erfaring og observasjon av praksis, samt tilbakemeldinger fra brukerne, skal forskning bidra til informerte beslutninger om bibliotekenes tjenester og tilbud.

Hvordan etterfølge bibliotekutredningen i praksis? Booth (2009) foreslår flere aktuelle tiltak og aktiviteter, blant annet å integrere kunnskapsbasert praksis i bibliotekets virksomhetsstrategi. Han presiserer at dette ikke nødvendigvis trenger å gjelde alle strategiområdene, men at man heller velger ut ett til to hovedområder der dette vurderes som særlig viktig. Ved Universitetsbiblioteket i Bergen gjøres nettopp dette. Biblioteket har en felles strategi for hele virksomheten (Universitetsbiblioteket, 2009). I tillegg utarbeides det årlig konkrete tiltaksplaner for å sikre at strategien følges opp i praksis. Kunnskapsbasert praksis er nevnt konkret som tiltak for å bidra til (1) høy studiekvalitet og godt læringsmiljø blant ansatte og studenter, og (2) som et ledd i bibliotekpersonalets egen kompetanseutvikling (Universitetsbiblioteket, 2010).

Booth (2009) foreslår også å praktisere kunnskapsbasert prosjektarbeid. Mange fagbibliotekarer er involvert i små eller store prosjekter. I prosjektet er det gjerne ett eller flere tiltak som skal settes ut i livet, eller man skal kartlegge mulige tiltak og tjenester. Her er gjerne egne og andres erfaringer, eventuelt supplert med lokale brukerdata, de informasjons- kildene som gir raskest svar og er mest tilgjengelig. Det raskeste svaret er imidlertid ikke alltid det eneste rette. Forskningslitteraturen kan derfor gi nyttige innspill til hvilke tiltak som bør settes i verk, og hvilke man bør styre unna. Igjen vil jeg bruke et eksempel fra universitets- og høgskolemiljøet i Bergen. Her gikk bibliotekene fra Norges Handelshøyskole, Høgskolen i Bergen, og Universitetet i Bergen sammen om å lage et nettkurs i litteratursøk og oppgaveskriving for bachelor- og masterstudenter. Kurset heter Søk \& Skriv ${ }^{3}$ og ble lansert i 2007. Kurset ble utviklet på basis av en evaluering av tidligere undervisningspraksis, og evaluering underveis i prosjektet. I tillegg ble eksisterende fag- og forskningslitteratur om informasjonssøk og akademisk skriving brukt for å utforme kursinnholdet. I etterkant reflekterte bibliotekarene rundt selve prosjektprosessen. På den måten fulgte man trinnene i kunnskapsbasert praksis fra prosjektstart til -slutt (Skagen, 2008).

Til slutt vil jeg nevne lesegrupper, eller tidsskriftklubber, som virkemiddel til å fremme kunnskapsbasert bibliotekpraksis i fagbibliotek. Lesegrupper er en vanlig form for internopplæring blant helsepersonell og formålet er å holde seg faglig oppdatert og øke bruk av forskning for å besvare praksisnære spørsmål (Deenadayalan et al., 2008). Formatet kan også overføres til bibliotek, og det er blant annet prøvd ut i bibliotekene ved Høgskolen i Telemark og Høgskolen i Bergen. Gruppen består vanligvis av 5-10 personer som har samme yrkesbakgrunn og/eller jobber med samme tema. Ved Høgskolen i Bergen har bibliotekarer som jobber med undervisning og brukeropplæring dannet en lesegruppe. Selve møtet varer 1,5 timer og spørsmålet som skal belyses bestemmes på forhånd, som oftest på forrige gruppemøte. Én i gruppen har ansvar for å søke etter egnet forskningsartikkel, og sende denne ut i forkant av gruppemøtet sammen med egnet sjekkliste ${ }^{4}$ for å vurdere artikkelens metodiske kvalitet og relevans for praksis. Den samme personen leder også selve gruppemøtet. Ansvaret for å finne artikkel og lede møtet rullerer mellom gruppens medlemmer. Ved Høgskolen i Telemark, der biblioteket er lokalisert på fire ulike studiesteder i fylket, har bibliotekarene brukt videokonferanse for å gjennomføre gruppemøtene.

\section{Utdanning og kurs}

$\AA$ arbeide kunnskapsbasert fordrer en viss kompetanse i metode og statistikk, og slik kompetanse bør 
bygges allerede i grunnutdanningen. Høgskolen i Oslo innførte i 2008 et eget emne i studieplanen for bachelorstudiene i bibliotek- og informasjonsfag kalt kunnskapsbasert bibliotekpraksis (Gjestum, 2009). Emnet har vært knyttet til studentenes praksisperiode andre studieår, og integrert med undervisning $\mathrm{i}$ kvantitative og kvalitative samfunnsfaglige metoder. Gjennom deltakelse i emnet og praksis skulle studentene få tilstrekkelig metodekunnskap for å kunne vurdere eksisterende bibliotekforskning, samt gjennomføre en enklere undersøkelse på egen praksisplass. I nåværende studieplan heter emnet "Undersøkelsesmetoder i teori og praksis", men innhold og organisering er til dels likt.

I 2007 ble det etablert en egen videreutdanning i kunnskapsbasert praksis for bibliotekarer ved Høgskolen i Bergen. Utdanningen ble i utgangspunktet initiert for å øke bibliotekarers kompetanse innenfor kunnskapsbasert praksis i helse- og sosialfag. Da studieprogrammet ble sendt på høring til representanter i målgruppen, var tilbakemeldingene at utdanningen også måtte trekke inn litteratur og undervisning relatert til kunnskapsbasert bibliotekpraksis. Utdanningens formål er derfor å øke bibliotekarens kunnskap og ferdigheter i å finne, velge ut, og vurdere forskning relevant for helse- og sosialfagene, samt å bruke resultat fra bibliotek- og informasjonsfaglig forsking for å informere og evaluere bibliotekpraksis (Høgskolen i Bergen, 2011). Hittil har 40 fagbibliotekarer fra utdanningssektoren, sykehus, og helseforvaltningen fullført utdanningen. Et nytt kull studenter tas opp våren 2011.

I tillegg til de akkrediterte studietilbudene har det vært arrangert kortere kurs og seminarer om kunnskapsbasert bibliotekpraksis for ansatte i fag- og folkebibliotek, med bidrag fra internasjonale kapasiteter på feltet. Helen Partridge fra Australia foreleste om temaet for et fullsatt auditorium i november 2009, da hun var gjesteforsker ved Avdeling for journalistikk, bibliotek- og informasjonsfag ved Høgskolen i Oslo. Senter for kunnskapsbasert praksis ved Høgskolen i Bergen har ved to anledninger invitert til seminar med Andrew Booth fra Sheffield University som kursholder og inspirator. Til sammen deltok seksti bibliotekarer på de to seminarene, de fleste av dem fagbibliotekarer. I skrivende stund tilbyr Høgskolen i Oslo et interaktivt og praktisk kurs i statistikk for både fag- og folkebibliotekarer, siste kursuke avhol- des i februar og avsluttes med et dagsseminar om kunnskapsbasert bibliotekpraksis.

\section{Fremtidsutsikter}

Hittil har jeg gitt noen eksempler på hvordan kunnskapsbasert praksis er integrert i norske fagbibliotek, samt vist til eksisterende utdannings- og kurstilbud. Det er per i dag ikke gjort noen systematiske undersøkelser av hvordan og i hvilken grad kunnskapsbasert praksis er implementert i bibliotekene, og heller ikke hvilke holdninger bibliotekarer har til slik praksis. En slik kartlegging vil kunne gi nyttig kunnskap om hva som hemmer og fremmer kunnskapsbasert bibliotekpraksis, for så å skreddersy og evaluere målrettede tiltak i praksis og utdanning.

Én av forutsetningene for kunnskapsbasert praksis er at relevant forskning er tilgjengelig for praksisfeltet. Ordet "tilgjengelig" kan her forstås både i betydningen "tilgang til" og "forståelig". I det norske bibliotekmiljøet har flere tatt til orde for at det etableres et nasjonalt fagmiljø á la Nasjonalt kunnskapssenter for helsetjenesten, med ansvar for å oppsummere og formidle forskning på bibliotekfaglige spørsmål (Audunson, 2009; Norsk bibliotekforening 2006). Systematiske oversikter er relevante for bibliotekfeltet, men samtidig har den bibliotekfaglige forskningslitteraturen flere begrensninger: Like spørsmål er besvart ved hjelp av ulike metoder, og forskere velger ofte utilstrekkelige metoder for å besvare spørsmålene sine (Rosall et al., 2008). Derfor er det ikke usannsynlig at et flertall av oversiktene vil konkludere med at det er behov for mer forskning.

$\AA ̊$ avdekke kunnskapshull er i seg selv et viktig funn i systematiske oversikter. For å tette kunnskapshullene trenger bibliotekfeltet flere forskere. Rosall og medarbeidere (2008) tar derfor til orde for at kunnskapsbasert bibliotekpraksis både handler om å konsumere forskning (anvende eksisterende forskning i daglig bibliotekpraksis) og å generere forskning (å selv forske på praksis). Fagbibliotekarer kan selv utvikle forskerkompetanse gjennom å involvere seg i eksisterende forskningsnettverk, og etter hvert etablere egne nettverk. Videre kan man samarbeide tettere med erfarne forskere, for eksempel ved å be om å få bidra med mer i prosjekter enn kun å gjøre litteratursøk. 


\section{Oppsummering og konklusjon}

Kunnskapsbasert praksis i fagbibliotek har to dimensjoner. I denne artikkelen har jeg belyst hvordan begge dimensjonene er til stede i norske fagbibliotek. På den ene siden er fagbibliotekaren en støttespiller for slik praksis blant andre profesjoner, for eksempel gjennom undervisning, som medarbeider i systematiske kunnskapsoppsummeringer, eller ved å ta direkte del i brukerens praksis (for eksempel gjennom kliniske bibliotekartjenester). På den andre siden anvender fagbibliotekaren selv prinsippene for kunnskapsbasert praksis på bibliotekfaglige spørsmål, men en større kartlegging er nødvendig for å si noe om omfanget av slik praksis i bibliotekene.

De to dimensjonene er ikke gjensidig utelukkende, de overlapper hverandre. Fagbibliotekarer holder eksempelvis kurs i litteratursøk for å støtte kunnskapsbasert praksis blant andre faggrupper. Men er det best å undervise brukerne ansikt til ansikt, eller er det like effektivt å lage et nettundervisningsprogram? Dette spørsmålet har forskere forsøkt å besvare (se for eksempel Koufogiannakis \& Wiebe, 2007). Når bibliotekaren aktivt bruker kunnskap fra denne forskningsbasen for å tilrettelegge undervisningen sin, praktiserer han eller hun selv kunnskapsbasert. Samtidig blir denne kunnskapen blir brukt til å støtte kunnskapsbasert praksis blant sluttbrukerne.

\section{Noter}

1. Cochrane Library er en database som inneholder systematiske oversikter og kontrollerte studier over effekt av forebygging og behandling.

2. Se www.helsebiblioteket.no

3. Se www.sokogskriv.no

4. Eksempler på sjekklister finnes på: http://www. newcastle.edu.au/service/library/gosford/ebl/toolkit/appraise.html

\section{Referanser}

ABM-utvikling (2006). Bibliotekereform 2014: Del I Strategier og tiltak. ABM-skrift 30. Oslo, ABM-utvikling. Tilgjengelig fra: http://www.abm-utvikling. no/publisert/abm-skrift/bibliotekreform2014_del1. pdf [Nedlastet 29.01.2011].
Audunson, R (2009). Fra synsing til kunnskapsbasert praksis. Bok og Bibliotek, 2: 12-13.

Bjørndal, A, Flottorp, S \& Klovning A (2000). Medisinsk kunnskapshåndtering. Oslo, Gyldendal Akademisk.

Booth, A (2009). Using evidence in practice: eleven steps to EBLIP service. Health Information and Libraries Journal, 26(1), 81-84.

Booth, A, \& Brice, A (red) (2004). Evidence-based practice for information professionals: a handbook. London: Facet Publishing.

Deenadayalan, Y et al. (2008). How to run an effective journal club: a systematic review. Journal of Evaluation in Clinical Practice, 14(5), 898-911.

Gjestrum, L (2009). Kunnskapsbasert praksis: erfaringene med kunnskapsbasert bibliotekpraksis 2. studieår. Bibliotekaren, 2: 18-19.

Grant, MJ \& Booth, A (2009). A typology of reviews: an analysis of 14 review types and associated methodologies. Health Information and Libraries Journal, 26(2), 91-108.

Grimen, H \& Terum, LI (red.) (2009). Evidensbasert profesjonsutøvelse. Oslo: Abstrakt forlag.

Høgskolen i Oslo (27.01.2011) Kunnskapsbasert praksis for bibliotekarer. Tilgjengelig fra http://student.hib.no/fagplaner/ahs/fagplan. asp?kode=B15BIBKUNN [Nedlastet 29.01.2011].

Koufogiannakis, D, \& Wiebe, N (2006). Effective methods for teaching information literacy skills to undergraduate students: a systematic review and meta-analysis. Evidence Based Library and Information Practice, 1: 3-21.

Norsk bibliotekforening (2006). Bibliotekreform. Tilgjengelig fra: http://www.norskbibliotekforening. no/index.php? $=340 \&$ kat $=$ BibliotekReform [Nedlastet 30.01.2011].

Rosall, H et al. (2008). Developing research capacity in health librarians: a review of the evidence. Health Information and Libraries Journal, 25(3): 159-74. 
Skagen, T (2008). Biblioteket og kunnskapsbasert praksis: prosjektarbeid som et alternativ. Fagreferentkonferansen 2008. Universitetsbiblioteket i Oslo, Oslo, juni 2008.

Universitetsbiblioteket i Bergen (2009). Strategisk plan 2010-2015 for Universitetsbiblioteket. Bergen: UB. Tilgjengelig fra: http://www.ub.uib.no/fel-
les/dok/strategi/Strategisk-plan-UB-2010-2015.pdf [Nedlastet 29.01.2011].

Universitetsbiblioteket i Bergen (2010). Tiltaksplan 2010 for Universitetsbiblioteket. Bergen :UB. Tilgjengelig fra: http://www.ub.uib.no/felles/dok/strategi/Tiltaksplan-UB-2010-100215.pdf [Nedlastet 29.01.2011]. 